\title{
MEDICINE
}

\section{EARLY DIAGNOSIS OF KIDNEY DISEASE IN CHRONIC OBSTRUCTIVE DISEASE OF LUNG PROBLEMS COMBORIDE STATES IN THE CONDITIONS OF THE LOW ALTITUDE}

\author{
Dolgalev D. V., aspirant Kyrgyz State Medical Institute Retraining and Professional Development, \\ Kyrgyzstan, Bishkek
}

Kaliev R. R., PhD Kyrgyz State Medical Academy, Kyrgyzstan, Bichkek

DOI: https://doi.org/10.31435/rsglobal_wos/30122019/6841

\section{ARTICLE INFO}

Received: 22 October 2019

Accepted: 19 December 2019

Published: 30 December 2019

\section{KEYWORDS}

moderately increased albuminuria, chronic kidney disease, chronic obstructive pulmonary disease,

urogenital system pathology.

\begin{abstract}
The high incidence of concomitant pathology on the part of the renal system can lead to a mutual burden of various diseases, which in turn requires additional methods of examination, prevention, and further mandatory medical correction in patients with chronic obstructive pulmonary disease.

Objective: to identify a moderately increased albuminuria and analysis of the functional state of the kidneys in chronic obstructive pulmonary disease in low altitude at an earlier stage of its manifestation.

Material and methods: 82 low-altitude patients (Tokmok) were examined with COPD of varying severity, as well as 10 healthy individuals. The average age was $60.53+15.48$ years. In addition to general clinical examination, patients underwent an early marker of damage to the MIA, assessment of the function of external respiration and indicators of renal function, which included the calculation of glomerular filtration rate (GFR), analyzes of proteinuria, leukocyturia, hematuria, total protein and serum creatinine.

Results: In patients with COPD, an early and significant change in renal function indices is noticeably observed, which in turn tends to correlate with the degree of bronchial obstruction.
\end{abstract}

Citation: Dolgalev D. V., Kaliev R. R. (2019) Early Diagnosis of Kidney Disease in Chronic Obstructive Disease of Lung Problems Comboride States in the Conditions of the Low Altitude. International Academy Journal Web of Scholar. 12(42). doi: 10.31435/rsglobal_wos/30122019/6841

Copyright: (C) 2019 Dolgalev D. V., Kaliev R. R. This is an open-access article distributed under the terms of the Creative Commons Attribution License (CC BY). The use, distribution or reproduction in other forums is permitted, provided the original author(s) or licensor are credited and that the original publication in this journal is cited, in accordance with accepted academic practice. No use, distribution or reproduction is permitted which does not comply with these terms.

Introduction. Chronic obstructive pulmonary disease (COPD) and diseases of the genitourinary system in combination, according to various studies, ranges from $32 \%$ [1] to $47.3 \%$ [2]. Many studies indicate a high frequency of changes in the kidneys in patients with COPD, which is $60.5 \%$ by sectional data [3]. The most likely and significant reasons that lead to a similar combination of pathology of the lungs and kidneys include the identified genetic predisposition, as well as tobacco dependence as the most aggressive risk factor [4-6, 18, 19, 25-26]. In everyday clinical practice, there is a significant underestimation of the manifestation of the incidence of renal dysfunction in patients with COPD, while in-depth and more targeted studies of this cohort reveal changes in renal tissue function. In determining and shaping pathological processes in the renal system, the most important role is played by such factors as the infectious, toxic, hypoxemic, and circulatory mechanisms associated with changes in the lungs. Determining the account of the resulting structural and functional disorders in the respiratory system entails changes in homeostasis, in the cardiovascular 
system [36, 37], anemia, a violation of mineral metabolism in bone tissue, anxiety-depressive, mental disorders [38, 39], and renal dysfunction [40]. Also, the presence of chronic kidney disease (CKD) in patients hospitalized with exacerbation of COPD is associated with an increased mortality rate [41]. There is evidence that impaired renal function in patients with COPD progresses in parallel with the severity of the underlying disease and further mechanisms leading to a progressive decrease in renal plasma flow, tubular reabsorption, glomerular filtration rate (GFR), blood flow with increased renal vascular resistance $[7-10,20,21]$. Thus, D.S. Nurgazieva in the study of GFR in patients with COPD noted that most patients have stage II CKD [42].

There is evidence of some authors who simultaneously display changing morphological structures in the affected lungs, which in turn complicates, and in the future, exacerbates, the course of chronic kidney diseases $[11,12,22]$. Studies conducted by numerous authors distinguish the following main pathogenetic mechanisms leading to kidney damage:

activation of the renin-angiotensin-aldosterone system;

imbalance between the NO system and reactive oxygen species;

inflammation;

hyperactivation of the sympathetic nervous system [13-17, 23-24].

There is evidence that one of the earliest markers of renal damage, namely the glomerular filtration barrier, is moderately increased albuminuria (MIA). Patients with a history of arterial hypertension, diabetes mellitus, these indicators are closely interrelated with the cardiovascular risk factor, increased frequency of coronary heart disease (coronary heart disease), and further worsening of the prognosis of the disease [27]. Several studies have described a continuous relationship between cardiovascular and non-cardiovascular mortality on the one hand and MIA on the other [28-30]. Establishing and determining the assessment of MIA in pulmonary pathology, in particular in COPD, is devoted to only a few studies. Vulcun E. et al. [31] report its higher frequency among patients with COPD and a close almost linear relationship with the degree of saturation of hemoglobin with oxygen. Similar data are provided by Casanova C. et al. [32-34]. The authors emphasize that the relationship between MIA with the degree of hypoxia for varying severity of COPD, as well as its further prognostic role in the future with this nasology, is currently unclear.

The aim of the study is to study the frequency of MIA, as well as the features of the urinary system and its functional state in patients with COPD, depending on the severity, which will subsequently allow a comparative analysis of the revealed clinical and functional disorders.

Material and methods. 82 patients were examined in low-mountain conditions (Tokmok, Kyrgyz Republic, located at 762 meters above sea level), of which 38 were men and 44 were women with COPD with varying severity. The average age of which was $60.53 \pm 15.48$ years. The diagnosis and assessment of the severity of COPD were established in accordance with the criteria of the Global Initiative for Chronic Obstructive Lung Disease (GOLD, 2011).

In the examined patients, we analyzed such indicators as the function of external respiration (HFD): forced expiratory volume in 1 second (FEV 1\%), instantaneous expiratory flow rate at 25, 50, $75 \%, 1 / \mathrm{s}(\operatorname{MOS} 25$, MOS50, MOS75 $1 / \mathrm{sec})$, Tiffno index, forced expiratory volume in 1 second / forced vital capacity of the lungs (FEV $1 / \mathrm{FVC} \%)$. Along with an assessment of the severity, we simultaneously studied the clinical symptoms characteristic of each of them, such as coughing, shortness of breath at rest and after physical activity, and the presence of sputum. Given the severity of COPD, all patients were divided into three groups. The first group consisted of 27 patients with mild COPD. The second group included 32 patients with moderate severity of COPD, and the third group included 23 patients with severe COPD. All groups of patients were comparable among themselves by sex and age. The control group (CG) consisted of 10 healthy individuals, which are comparable in gender and age with the main group of tested patients. The detection of MIA was determined using the microalbuphan Albu test (Erbalachema). The total parameters of the renal function were evaluated by calculating the glomerular filtration rate $(\mathrm{rSCF})$. At the same time, analyzes of proteinuria, leukocyturia, hematuria, the concentration of total protein and serum creatinine were performed.

The obtained statistics were processed using the STATISTICA 6.0 program. The results of statistical processing are presented as mean \pm standard deviation. The normality of the distribution was determined by the criteria of Shapiro-Wilk and Lillefors. The reliability of the differences between the groups of subjects was determined using the non-parametric Mann-Whitney test, as well as the parametric student t-test. For multiple statistical comparisons, the Kruskal-Wallis criteria were used, 
and variance analysis was determined with the calculation of the coefficient $\mathrm{F}$ and subsequent post-hoc analysis. The obtained differences were considered significant at $\mathrm{p}<0.05$.

Research results. Indicators of external respiration function among patients analyzed groups are presented in Fig. 1

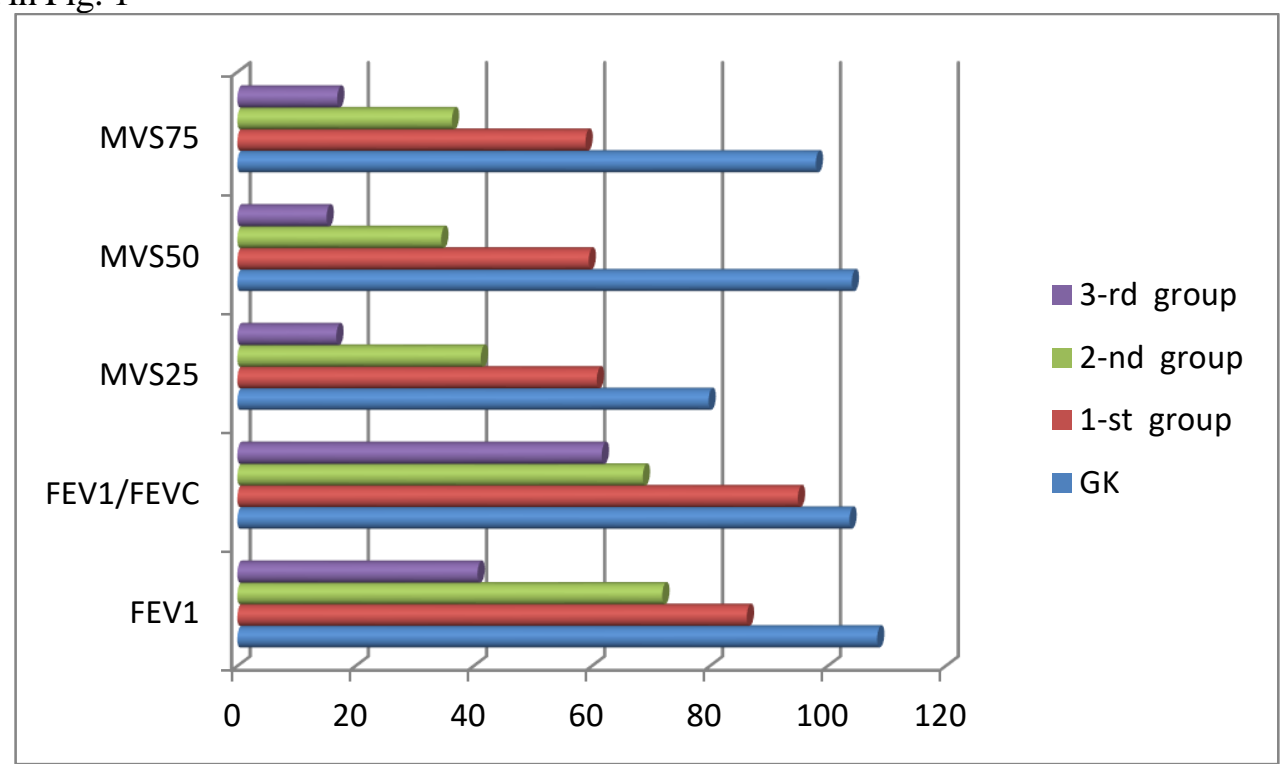

Fig. 1. EBF depending on the severity of chronic obstructive pulmonary disease.

Note: $*$ p $<0.01$ compared with the control group; differences between the groups of patients with COPD are significant $(\mathrm{p}<0.01)$. The values of bronchial patency were found to be significantly reduced in patients with COPD compared with the group of healthy individuals ( $p<0.01$ ) (Fig. 1).

At the same time, a regular worsening of ventilation indices was noted as the disease progressed $(\mathrm{p}<0.01)$.

The obtained statistics were processed using the STATISTICA 6.0 program. The results of statistical processing are presented as mean \pm standard deviation. The normality of the distribution was determined by the criteria of Shapiro-Wilk and Lillefors. The reliability of the differences between the groups of subjects was determined using the non-parametric Mann-Whitney test, as well as the parametric student t-test. For multiple statistical comparisons, the Kruskal-Wallis criteria were used, and variance analysis was determined with the calculation of the coefficient $\mathrm{F}$ and subsequent post-hoc analysis. The obtained differences were considered significant at $\mathrm{p}<0.05$.

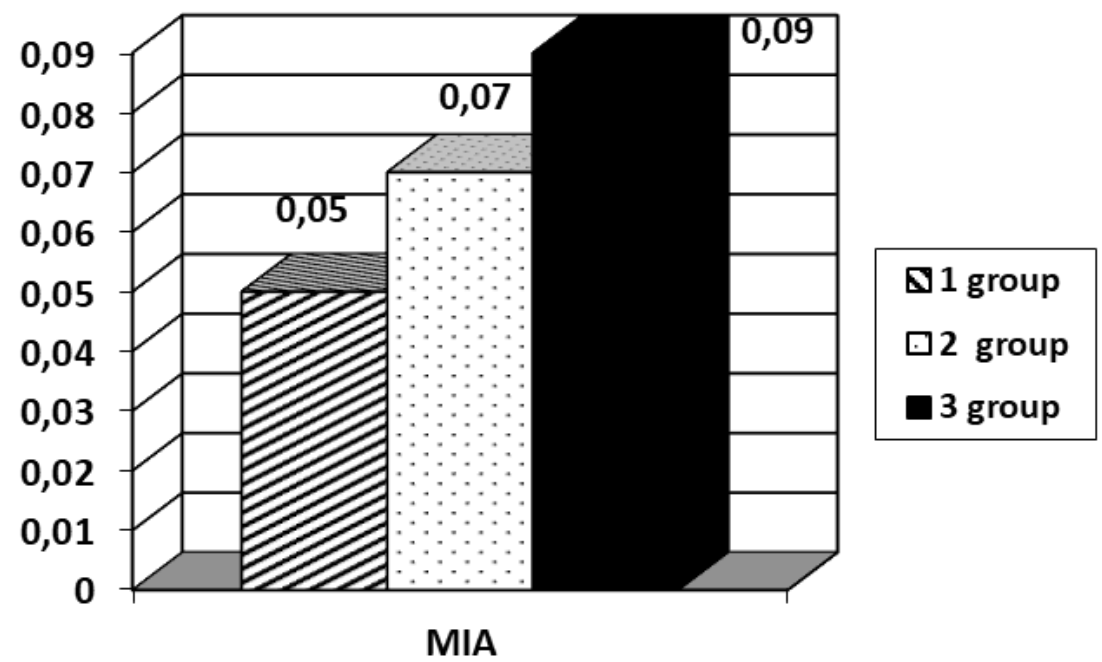

Fig. 2. Indicators of moderately increased (micro) -albuminuria depending on the severity of COPD

Finding out the parameters of MIA with an increase in bronchial obstruction in COPD, we obtained the following results. MIA in patients of the 2nd group was $0.07 \pm 0.04 \mathrm{~g} / 1$, which tended to rise than in patients with mild COPD $(0.05 \pm 0.03 \mathrm{~g} / 1, \mathrm{p}>0.05)$ Pronounced MIA was observed in patients with severe 
course of bronchial obstruction, which reached $0.09 \pm 0.03 \mathrm{~g} / 1$ and significantly superior to similar parameters in the subjects, both in the 1st ( $\mathrm{p}<0.001)$ and in the 2 nd group ( $<0.05)$, respectively (Fig. 2$)$.

Studying the relationship of changes in renal function with the severity of broncho-obstructive syndrome, the following data were recorded. Compared with the control group, COPD patients had significantly low rates of filtration function and this was expressed in an increase in serum creatinine concentration, as well as in a decrease in eGFR. A clear progressive deterioration in renal function was noted as the severity of broncho-obstructive syndrome increased. In particular, eGFR for mild, moderate to severe, and severe COPD was $98.0 \pm 11.3 \mathrm{ml} / \mathrm{min} / 1.73 \mathrm{~m}^{2}, 68.8 \pm 7.4 \mathrm{ml} / \mathrm{min} /$ $1.73 \mathrm{~m}^{2}$ and $64.5 \pm 5,5 \mathrm{ml} / \mathrm{min} / 1.73 \mathrm{~m}^{2}$, respectively $(\mathrm{p}<0.01)$. A similar dynamics was observed in the subjects with respect to the serum creatinine content $(\mathrm{p}<0.01)$ (Fig. 3$)$.

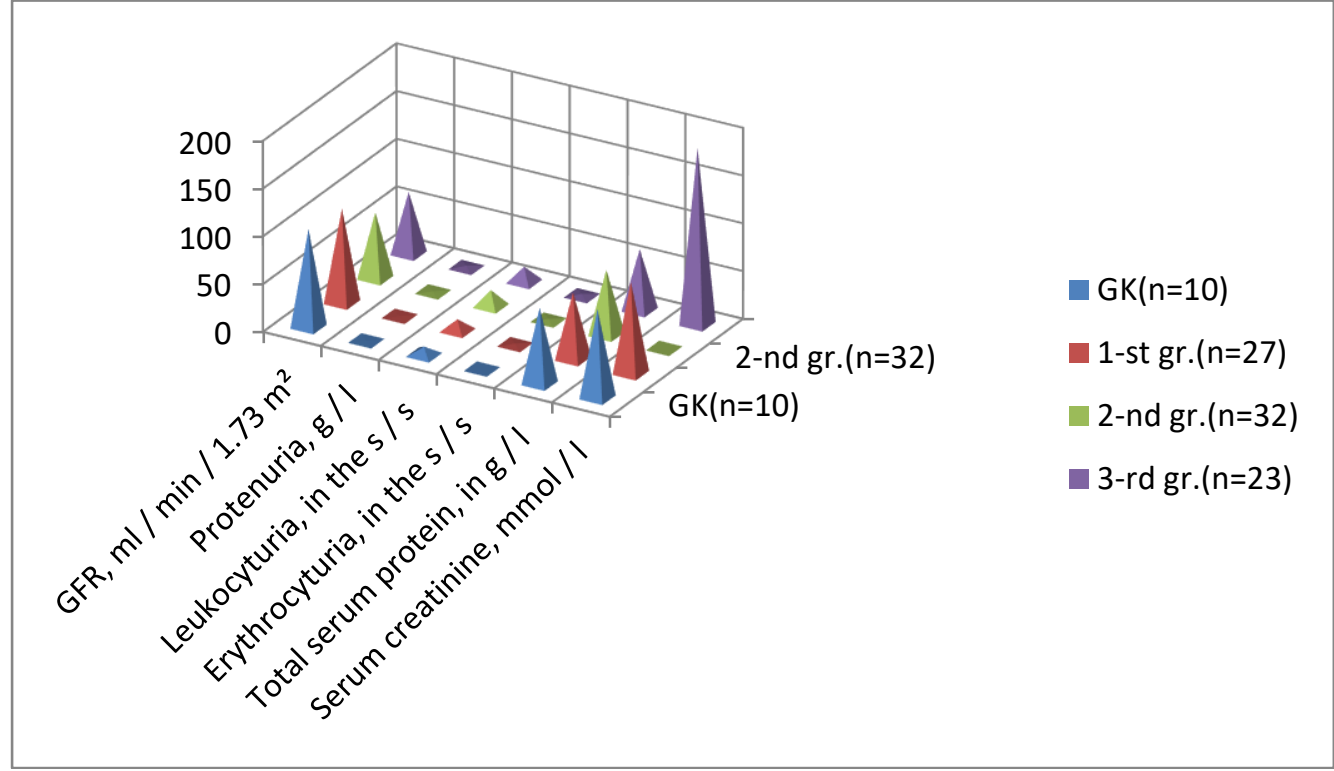

Fig. 3. Indicators of the functional state of the kidneys in patients depending on the severity of COPD Note: $*-p<0.01$ in comparison with the control group; ${ }^{\circ}-\mathrm{p}<0.05$ in comparison with patients with COPD of the 1st group; ${ }^{-}-\mathrm{p}<0.05$ in comparison with patients with COPD of the 2 nd group.

There was a steady increase in the degree of damage to the renal filter, as evidenced by an increase in the amount of protein in the urine with the progression of COPD $(0.39 \pm 0.09 \mathrm{~g} / 1,0.74 \pm$ $0.28 \mathrm{~g} / 1$ and $2.02 \pm 0.60 \mathrm{~g} / 1$ at stages $1-3$ of COPD, respectively, $\mathrm{p}<0.01$ between groups and $\mathrm{p}$ $<0.001$ compared with the control group) simultaneously with a parallel decrease in the concentration of total serum protein ( $\mathrm{p}<0.01$ ) (Fig. 3 ) Determining the analysis of the cellular composition of the urinary sediment, showed an increase in the number of leukocytes and red blood cells in patients with COPD ( $\mathrm{p}<0.01$ ), it should be noted that the greatest number of them in urinary sediment was recorded in patients with a severe course of this disease (Fig. 3).

We can agree with the results of numerous studies on the problem of COPD with systemic manifestations, when functional changes in the kidneys are clearly visible in patients. Our study revealed a progressive increase in MIA in low altitude (Tokmok) as the course of COPD worsens, which coincides with data from several scientific publications [32-34] on the relationship of the degree of hypoxemia in this disease with a violation of the glomerular filtration barrier. The most important aspect is the discovery of a direct association of the degree of MIA with the evolution of COPD, which subsequently allows us to consider it as a marker of the severity of the disease. This position is also consistent with our earlier obtained results in low altitude (Tokmok city), namely, a linear decrease in the filtration capacity of the kidneys as COPD increases [35]. In this aspect, further more detailed studies are needed to clarify the answer to the question posed: AS, along with GFR, is simply a marker of renal damage in COPD or all the same has an independent independent prognostic value for this associated pathology. The high incidence of concomitant pathology from the genitourinary system leads to a mutual burden of diseases and other systems. Determining the presence of signs of a pathology of the genitourinary system in patients with COPD, which in turn requires an additional, detailed examination for subsequent prevention and further medical correction. 
Conclusions. 1. The detection in the low altitude of a moderately increased (micro) albuminuria is the earliest marker of renal filter damage in COPD, which is noted in patients with a mild course of the disease, and also tends to increase further as it progresses.

2. Patients with COPD in low altitude show significant changes in renal function indicators, which correlate with the degree of bronchial obstruction.

\section{REFERENCES}

1. Shelepenko A.F., Mironov М. В., Sidorov J.A. The association visceral a pathology at patients ХОБЛ. 16th National Congress by pulmonary disease. St.- Petersburg 2006:238.

2. Kirillov M. M, Shashina M. M, Bocharov A.V., etc. Pathology of kidneys at nonspecific diseases of lungs. Pulmonology 2000; 2: $84-87$.

3. Mashencheva E.V. The association a pathology at lungs sick of chronic obstructive pulmonary disease. 17th National Congress by pulmonary disease. Kazan 2007:239.

4. Shishkin A.N. Smoking and a nephritic pathology. New St.-Petersburg medical sheets 2004; 4: $112-116$.

5. Кароли Н. А., Ребров А. П. Эндотелиальная дисфункция и ее клиническое значение у больных хронической обструктивной болезнью легких // Клин.мед. 2005; 9: 10-16.

6. Halimi J. M., Vol S. et al. Effect of current smoking and smoking discontinuation on renal function and proteinuria in the general population // Kidney Int. 2000; 58: 1285-1292.

7. Pinto-Sietsma S.J., Mulder J., Janssen W.M. et al. Smoking is related to albuminuria and abnormal renal function in nondiabetic persons. Ann. Intern. Med. 2000; 133 (8: 585) -591.

8. Ivanova D.A., Sporova O. E, Belenkova S.V., Statsenko M. E. Features of a functional condition of kidneys at patients CHF (chronic heart failure) and chronic obstructive pulmonary disease. I congress of a society of experts in heart failure. Moscow 2006:62.

9. Mukonina V. N. Proteinuria at lungs sick of chronic obstructive pulmonary disease. Xth the National Congress by pulmonary disease. St.- Petersburg 2000:305.

10. Vohmintseva I.V., Menshikov I.G. Diagnostics of the latent infringements of a nephritic blood-groove at sick of a chronic obstructive bronchitis. XI th National Congress by pulmonary disease. Moscow, 2001:145.

11. Brodskaja T.A., Nevzorov V. A, Geltser B.I., Motkina E.V. Endothelial dysfunction and chronic diseases of lungs. Rubbed. Archive 2007; 3: 76 -84.

12. Batyraliev T.A., Mahmudhodzhaev S.A., Pataraja S.A., etc. Pulmonary hypertensia and right ventricular dysfunction. A part IV. Chronic diseases of lungs. Cardiology 2006; 5: 77 -88.

13. MacNee W. Pathophysiology of corpulmonale in chronic obstructive pulmonary disease. Am. Rev. Respir. Dis. 1994; 150: 833 -852.

14. Kanazawa Y., Shiraishi S., Hirata K., Yashikawa J. Imbalance between levels of nitrogen oxides and peroxynitrite inhibitory activity in chronic obstructive pulmonary disease. Thorax 2003; 58: $106-109$.

15. Gan W.Q., Man S.F., Senthilselvan A., Sin D.D. The association between chronic obstructive pulmonary disease and systemic inflammation: a systematic review and a meta-analysis. Thorax 2004; 59:574-580.

16. Avdeev S. System effects at patients COPD. The doctor 2006; 12:3-10.

17. Chuchalin A.G. Respiratory medicine. M: Geotar-media; 2007. 593 - 605.

18. Maslov O. I, Landyshev J.S., Lenshin A.V. Function of external breath and feature regional ventilation of lungs at patients with chronic renal failure. Pacific medical magazine 2004; 4 (18: 44$)-46$

19. Авдеев С.Н. Хроническая обструктивная болезнь легких как системное заболевание // Пульмонология 2007; Т.2: 104-116.

20. Чучалин А.Г. Хроническая обструктивная болезнь легких и сопутствующие заболевания Часть II. Хроническая обструктивная болезнь легких и не кардиальные поражения // Российский медицинский журнал 2013; Т.16: 246-249

21. Шойхет Я.Н., Клестер Е.Б. Патология мочеполовой системы у больных с хронической обструктивной болезнью легких в сочетании с ишемической болезнью сердца // Клин.медицина 2008; Т.10: 23-28.

22. Бугаенко В.В., Слободской В.А., Товстуха В.В. Коморбидные состояния: ишемическая болезнь сердца и хроническое обструктивное заболевание легких // Украинский кардиологический портал 2011; Т.5: $72-78$

23. Чучалин А.Г. Хроническая обструктивная болезнь легких и сопутствующие заболевания // Пульмонология 2008; Т.2: 5-14.

24. Бродская Т.А. Невзорова В.А. Гельцер Б.И. и др. Дисфункция эндотелия и болезни органов дыхания // Tep.apx. 2007; 3: 76-84.

25. Дзгоева Ф. У., Кутырина И. М., Мусселиус С. Г. и др. Дисфункция эндотелия при тяжелых формах острой почечной недостаточности. Новые подходы к патогенетической терапии // Тер.арх. 2005; 6:35-39.

26. Orth S.R. Smoking - a renal risk factor. Nephron 2000; 86: $12-26$

27. Chuahirun T., Khanna A., Kimball K. et al. Cigarette smoking and increased urine albumin excretion are interrelated predictors of nephropathy progression in type 2 diabetes // Kidney Disease 2003; 41: 13-21.

28. Hemlin M., Ljungman S., Carlson J. et al. The effects of hypoxia and hypercapnia on renal and heart function, haemodynamics and plasma hormone levels in stable COPD patients // Clin Respiratory 2007; 1 (2): 80-90.

29. Parving H.H. Initiation and progression of diabetic nephropathy. N Engl J Med 1996; 335: 1682-1683.

30. Ruilope L.M., Rodicio J.L. Clinical relevance of proteinuria and microalbuminuria. Curr Opin Nephrol Hypertens 1993; 2: 962-967. 
31. Hellege H. L., Fidler V., Diercks G., F. et al. Urinary albumin excretion predicts cardiovascular and noncardiovascular mortality in general population/ Circulation 2002; 106: 1777-1782.

32. Bulcun E., Ekici M., Ekici A., Kisa U. Microalbuminuria in chronic obstructive pulmonary disease. COPD 2013; 10(2): 92-186.

33. Casanova C., Torres J.P., Navarro J. et al. Microalbuminuria and hypoxemia in patients with chronic obstructive pulmonary disease. Respir Crit Care Med. 2010; 182(8): 1004-1010.

34. Bulcun E., Ekici M., Ekici A. et al. Microalbuminuria in obstructive sleep apnea syndrome. Sleep Breath 2015. [Epub ahead of print].

35. Долгалев Д.В., Ибрагимов А.А., Калиев Р.Р. Функциональное состояние почек при хронической обструктивной болезни легких в условиях низкогорья. //Вестник КГМА 2015; 3:57-61.

36. Малыш Е.Ю., Дробышева Е. С., Чернов А.В. Хроническая обструктивная болезнь легких и поражение сердечно-сосудистой системы // Молодой ученый. 2014. №5(64). С.145-148. URL: https://moluch.ru/ archive/64/10267/ (дата обращения: 17.01.2018).

37. Малыш Е.Ю., Овсянников Е.С., Семынина Н.М., Чернов А.В. Состояние вегетативной нервной системы у больных хронической обструктивной болезнью легких и артериальной гипертензией // Врач-аспирант. 2014. Т.63, №2.1. С.186-191.

38. Чучалин А.Г., Авдеев С.Н., Айсанов 3.Р., Белевский А.С., Лещенко И.В., Мещерякова Н.Н., Овчаренко С.И., Шмелев Е.И. Российское респираторное общество. Федеральные клинические рекомендации по диагностике и лечению хронической обструктивной болезни легких // Пульмонология. 2014. №3. С.15-54

39. Campo G., Pavasini R., Malagi M., Mascetti S., Biscaglia S., Ceconi C., Papi A., Contoli M. Chronic obstructive pulmonary disease and ischemic heart disease comorbidity: overview of mechanisms and clinical management// Cardiovasc. Drugs Ther. 2015. Vol.29, №2. P. 147-157. doi: 10.1007/s10557-014-6569-y

40. Fabbian F., De Giorgi A., Manfredini F., Lamberti N., Forcellini S., Storari A., Gallerani M., Caramori G., Manfredini R. Impact of renal dysfunction on in-hospital mortality of patients with severe chronic obstructive pulmonary disease: a single-center Italian study // Int. Urol. Nephrol. 2016. Vol.48, №7. P.1121-1127. doi: 10.1007/s11255-016-1272-5

41. Singanayagam A., Schembri S., Chalmers J.D. Predictors of mortality in hospitalized adults with acute exacerbation of chronic obstructive pulmonary disease // Ann. Am. Thorac. Soc. 2013. Vol.10, №2. P.81 89. doi: 10.1513/AnnalsATS.201208-0430C.

42. Нургазиева Д.С. Хроническая болезнь почек у пациентов с хронической обструктивной болезнью легких // Бюллетень медицинских Интернет-конференций. 2016. Т.6, № 5. С.518 